\title{
PREVALENCE OF CHAGAS DISEASE AMONG BLOOD DONOR CANDIDATES IN TRIANGULO MINEIRO, MINAS GERAIS STATE, BRAZIL
}

Patrícia da Silva LOPES(1), Eliezer Lucas Pires RAMOS(1), César GóMEZ-HERNÁNDEZ(2), Gabriela Lícia Santos FERREIRA(1) \& Karine REZENDE-OLIVEIRA(1)

\begin{abstract}
SUMMARY
Despite public health campaigns and epidemiological surveillance activities, Chagas disease remains a major health problem in Latin America. According to data from the World Health Organization, there are approximately 7-8 million people infected with Trypanosoma cruzi worldwide, a large percentage of which in Latin America. This study aims to examine the serological profile of blood donors in blood banks of Hemominas hematology center, in the town of Ituiutaba, Minas Gerais State, Brazil. The study sample consisted of 53,941 blood donors, which were grouped according to gender and age. Sample collections were performed from January 1991 to December 2011, and 277 donors $(0.5 \%)$ were considered serologically ineligible due to Chagas disease. Analysis of data showed no significant difference between genders. As for age, the highest proportion of ineligible donors was from 40 to 49 years (30\%), and there was a positive correlation between increasing age and the percentage of patients seropositive for Chagas disease. Therefore, adopting strategies that allow the safe identification of donors with positive serology for Chagas disease is essential to reduce or eliminate indeterminate serological results.
\end{abstract}

KEYWORDS: Prevalence; Chagas Disease; Donor.

\section{INTRODUCTION}

Trypanosoma cruzi, an obligate intracellular pathogen, is the etiologic agent of Chagas disease. Infection occurs after infected hematophagous insects (invertebrate hosts), feed on mammals ${ }^{13}$.

American trypanosomiasis, also known as Chagas disease, is an important endemic parasitic disease, a medical and social problem in Brazil and in several Latin American countries, having both an economic and public health impact ${ }^{7}$.

According to MONCAYO (1999) ${ }^{\mathbf{1 2}}$, there was a considerable decrease in the number of domiciliary infestation rates by domestic triatominae in Brazil from the 1980s to the 1990s because of the systematic actions taken against the vector in Latin America. Since then, blood transfusion became the main mode of transmission for Chagas disease ${ }^{4}$.

Studies on the prevalence of prospective blood donors with positive serology for Trypanosoma cruzi showed that they consisted of $6.8 \%$ in Latin America in the 1980s. Data from the Pan American Health Organization (PAHO $)^{15}$ show that the overall prevalence of chagasic blood donors was $1.3 \%$ in 2006, which is a significant decrease compared with the prevalence observed prior to the 1980s. Furthermore, there was a gradual decrease in the prevalence of seropositivity to Trypanosoma cruzi in Brazil. Around the 1950s, there was a prevalence of $8.3 \%$, which then decreased to $6.9 \%$ in the 1960 s and $1970 \mathrm{~s}$, to $3.2 \%$ in the late $1980 \mathrm{~s}$ and early $1990 \mathrm{~s}$, and then to $0.2 \%$ in $2005^{11,12,13}$.

Although the incidence of Chagas disease has significantly decreased due to public health campaigns aimed to eradicate the vector and due to appropriate control of blood donations and transfusions, the number of individuals already infected with $T$. cruzi is still an issue of primary concern. Moreover, these individuals may eventually develop chronic Chagas disease $\mathrm{e}^{4}$.

Studies on the epidemiological profile of $T$. cruzi infection by means of analysis of the prevalence of infection among blood donor candidates may be a sensitive indicator because they determine the risk parameters for Chagas disease. Therefore, the aim of this study was to investigate the seroprevalence of Chagas disease in blood donors over the past 20 years at the Hemocentro (regional hematology center) in the town of Ituiutaba, Triangulo Mineiro region, Minas Gerais State, Brazil.

\section{MATERIALS AND METHODS}

This study consisted of serological data analysis and interpretation

(1) Universidade Federal de Uberlândia, Faculdade de Ciências Integradas do Pontal, Ituiutaba, MG, Brasil.

(2) Universidade Federal do Triângulo Mineiro, Uberaba, MG, Brasil.

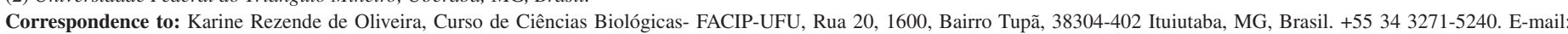
karinerezende.oliveira@gmail.com 
LOPES, P.S.; RAMOS, E.L.P.; GÓMEZ-HERNÁNDEZ, C.; FERREIRA, G.L.S. \& REZENDE-OLIVEIRA, K. - Prevalence of Chagas disease among blood donor candidates in Triangulo Mineiro, Minas Gerais State, Brazil. Rev. Inst. Med. Trop. Sao Paulo, 57(6): 461-5, 2015.

of blood donor candidates at the Hemocentro of Ituiutaba Town, Brazil. On average, 951 transfusions are performed there every year, equating to approximately $25 \%$ of donations (around 3,766 blood bags are collected annually). A retrospective database analysis was performed.

Records of blood donors with serological ineligibility were analyzed, i.e., donors with positive or indeterminate serology for Chagas disease.

Data from 53,941 female and male blood donors aged 18 to 60 years were selected. Among these, only gender and age of the ineligible serological group, either positive or indeterminate for Chagas disease, were analyzed.

The diagnostic tests were performed at the Hemocentro in Ituiutaba, where indirect hemagglutination (IHA) and indirect immunofluorescence (IIF) of the samples were recorded from 1991 to June 1995. Furthermore, IHA, IIF, and enzyme-linked immunosorbent assay (ELISA) of the samples were recorded from 1995 to July 1997, and IIF and ELISA (ABBOTT diagnostics, Brazil) were recorded from August 1997 to August 2011. Since 2003, the algorithm of tests used for diagnosis of Chagas disease have employed ELISA for screening, and IIF as a confirmatory assay. Sensitivity and specificity were $99.99 \%$ and $99.85 \%$, respectively. These tests were performed at the Hemocentro of Ituiutaba until April 2002 and, thereafter, at the Hemocentro of the city of Belo Horizonte, Minas Gerais State capital.

Donor candidates were classified into five age groups: A) under 20; B) 20-29; C) 30-39; D) 40-49; and E) over 50. The statistical methods used were as follows: univariate descriptive analysis, comparison of proportions, nonparametric chi-square test $(p<0.05)$, and correlation analysis using Spearman test. Statistica ${ }^{\circledR} 7.0$ software was used for this purpose.

\section{RESULTS}

From 1991 to 2011, 53,941 blood donations were collected at the Hemocentro in Ituiutaba, Minas Gerais State, Brazil. The results demonstrated ineligible serological prevalence in $0.5 \%$ of the donors (277) of whom $0.23 \%$ (129 donors) resulted serologically positive for Chagas disease, and $0.27 \%$ (148 donors) had indeterminate serological results. Within 20 years of sample collection, reagent cases (31 cases) were found to be prevalent from 1991 to 1995 . After this period, the prevalence of reagent cases decreased: 20 cases from 1996 to 2000, seven cases from 2001 to 2005, and ten cases from 2006 to 2011.

Donors that had abnormal serology for Chagas associated with other diseases were also observed, as follows: eight donors (2.9\%) had syphilis; 15 donors (5.4\%) were positive for hepatitis B (HBsAg); two donors $(0.7 \%)$ were positive for hepatitis $\mathrm{C}(\mathrm{HCV})$; and one donor $(0.4 \%)$ was positive for HIV. The serologically ineligible donor profiles were categorized by gender, with $76 \%$ (211) male donors and $24 \%$ (66) female donors.

Within the ineligible group, there was a rate of 33\% (91) positive donors in the male group, which was higher than in the female group, $14 \%$ (33), but this difference was not statistically significant $(p=0.057)$. The same result was observed when indeterminate serology was related to the gender of the donors within the ineligible group, with $43 \%$ (120) male donors and 10\% (28) female donors $(p>0.05)$. Importantly, male donors who were serologically ineligible tended to be more prevalent. Ineligible donors were also classified into five age groups, thus helping to establish a correlation between age and seropositivity for Chagas disease. This correlation was positive when the increasing age and the percentage of seropositive donors $(p=0.003 ; \mathrm{r}=0.98)$ were taken into account. Among all 277 ineligible donors in this study, there was a higher prevalence of donors within the following age groups: 84 donors $(30.3 \%)$ aged $40-49$ years; $73(26.3 \%)$ aged $30-39$ years; $58(20.9 \%)$ over 50 years; $47(16.9 \%)$ aged $20-29$ years; and 15 donors $(5.4 \%)$ up to 20 years. In the group with indeterminate serology, there was a random pattern of ages, with two vertices of higher incidence among donors aged 30-49 years. All the results are shown in Table 1. There was a decrease in the number of indeterminate and positive cases over 20 years, as shown in Figure 1.

\section{Table 1}

Prevalence of positive serology for Chagas disease: relation to age and gender of blood donor

\begin{tabular}{lccccc}
\hline \multirow{2}{*}{$\begin{array}{l}\text { Age } \\
\text { groups }\end{array}$} & \multicolumn{2}{c}{ Female } & \multicolumn{2}{c}{ Male } & \multirow{2}{*}{ Total } \\
\cline { 2 - 5 } & Positive & Indeterminate & Positive & Indeterminate & \\
\hline$<20$ & $0(0 \%)$ & $1(0.36 \%)$ & $3(1.08 \%)$ & $11(3.9 \%)$ & $15(5.4 \%)$ \\
$20-29$ & $1(0.36 \%)$ & $5(1.8 \%)$ & $12(4.3 \%)$ & $29(10.4 \%)$ & $47(16.9 \%)$ \\
$30-39$ & $8(2.8 \%)$ & $5(1.8 \%)$ & $26(9.3 \%)$ & $34(12.2 \%)$ & $73(26.3 \%)$ \\
$40-49$ & $16(5.7 \%)$ & $12(4.3 \%)$ & $29(10.4 \%)$ & $27(9.7 \%)$ & $84(30.3 \%)$ \\
$\geq 50$ & $13(4.6 \%)$ & $5(1.8 \%)$ & $21(7.5 \%)$ & $19(6.8 \%)$ & $58(20.9 \%)$ \\
\hline Total & $38(13.7 \%)$ & $28(10.1 \%)$ & $91(32.8 \%)$ & $120(43.3 \%)$ & $277(100 \%)$ \\
\hline
\end{tabular}

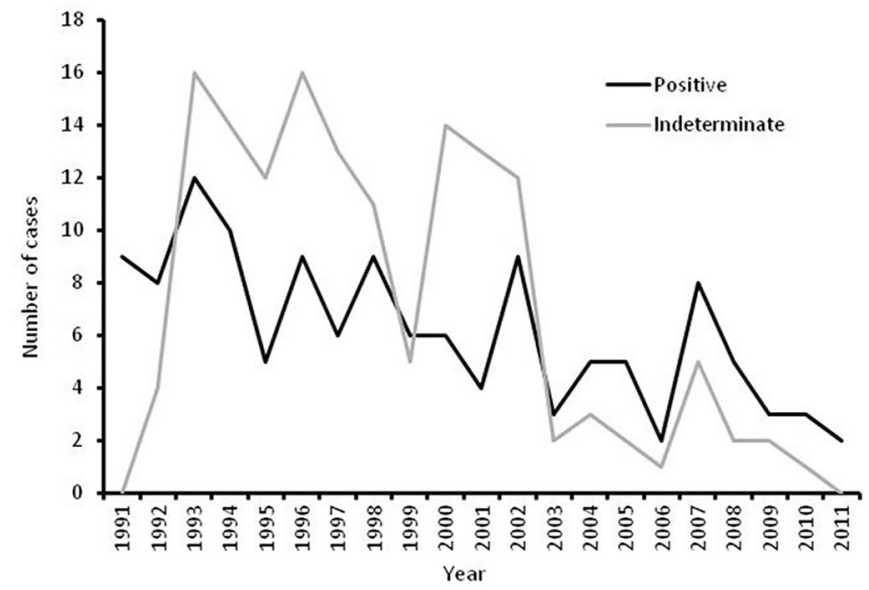

Fig. 1 - Indeterminate and positive cases of Chagas disease recorded in Hemominas, in Ituiutaba town, Minas Gerais State, Brazil.

\section{DISCUSSION}

Due to successful control measures taken against Chagas disease transmission, the International Commission comprised by the Pan American Health Organization (PAHO) and by the Southern Cone countries granted some Brazilian states a serological certification for the interruption of vectorial transmission of Chagas disease by Triatoma 


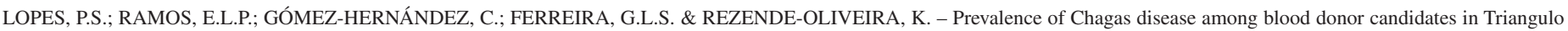
Mineiro, Minas Gerais State, Brazil. Rev. Inst. Med. Trop. Sao Paulo, 57(6): 461-5, 2015.

infestans, which contemplated Minas Gerais State. Thanks to successful vector control programs, blood transfusion is the second most common mode of transmission for Chagas disease in Latin America. Hence, non-negative donor screening is a challenge for blood bank staff, which ought to identify possible carriers of acute and chronic asymptomatic parasite $^{14,17}$.

The seroprevalence of $0.23 \%$ (129) donors for Chagas disease in this study is similar to that found in a study by OLIVEIRA et al. (2008), which reported a prevalence of $0.21 \%$. These data are in accordance with the World Health Organization findings (2002), which reported a rate of $1.3 \%$ in Latin America, and $0.2 \%$ in Brazil. The aforementioned rates were minor compared to the rates in the $1950 \mathrm{~s}$, in the $1960 \mathrm{~s}-70 \mathrm{~s}$, and in the $1980 \mathrm{~s}-90 \mathrm{~s}$, which were around $8 \%, 6 \%$ and $3 \%$, respectively ${ }^{10,19}$.

After analysis of the data in this study, 277 (0.5\%) donations were considered serologically ineligible for Chagas disease. These results are similar to studies by FITARELLI \& HORN $(2009)^{7}$, who noticed $150(0.41 \%)$ serologically ineligible donors for Chagas disease, and by LUNARDELLI (2007) $)^{9}$, who found a prevalence of $0.4 \%$. MORAESSOUZA et al. $(2006)^{13}$ observed that the occurrence of non-negative serology for Chagas disease among the donors at the regional Hemocentro in the town of Uberaba, from 2000 to $2004(0.31 \%)$, was similar to that in the present study; however, this study covers a period of 20 years ${ }^{1,6}$.

Analysis of the occurrence of serological ineligibility between genders was not found to be significant, despite the large number of male donors. According to the Brazilian National Health Foundation (FUNASA), there is a positive correlation between gender and positive serology for Chagas disease, since the disease is considered to indistinctly affect men and women. The predominance of male donors can be explained by cultural differences towards blood donation. In contrast to these results, MELO et al. (2009) ${ }^{11}$ reported that the contribution of male prevalence to Chagas disease was significantly lower compared to female prevalence $(p<0.0001)^{6,9,24}$.

The distribution of non-negative individuals in five age groups showed a progressive increase in seropositivity in the group aged 4049 years $(30.3 \%)$, and a decrease in the age group over $50(20.9 \%)$. Nonetheless, the low number of donors over the age of 50 explains the percentage decrease observed in this study. SOBREIRA et al. $(2001)^{22}$ also showed similar data, i.e., the group aged 40-49 years (37\%) had a higher frequency of donors seropositive for T. cruzi infection. Although the same was observed with indeterminate results, the ongoing increase in seropositivity was only found in the group aged $30-39$ years, and there was a decrease in the number of donors in the group over 50 years, which had also happened to positive donors. Similar results were demonstrated by MORAES-SOUZA et al. $(2006)^{13}$, who reported a higher percentage of donors aged 20-30 years 5 .

The percentage of disease prevalence in donors under 30 years is noticeably lower. The systematic actions carried out by national Chagas disease vector control programs since the 1970s may have contributed to maintenance of this low index in Brazil. However, further studies are necessary to confirm these observations. Since then, specific regulations have been adopted for blood donation in Brazil, as well as programs for recruitment, selection and retention of blood donors. The significant reduction in the prevalence of Chagas disease in blood donors is due to improved technical-scientific surveillance health measures conducted in partnership with hematology centers ${ }^{6,8}$.

Several factors, such as the sensitivity of serological tests for the diagnosis of Chagas disease, and clinical and serological screening protocols may influence the persistence of risk of transmission by blood transfusion.

ELISA test has been used for serological screening of blood banks for the detection of T. cruzi infection since the 1990s, because it is a sensitive and specific technique that uses different recombinant antigens which increase the reliability of the test ${ }^{23}$.

The high occurrence of indeterminate results $(53 \%)$ is in agreement with another study that, coincidentally, also obtained 53\% of ineligible serological results which were considered indeterminate. These reactions suggest the possibility of failure in the specificity of serological tests, since there may be cross-reactions with other antigenic determinants in the individual. It is difficult to address and instruct donors with indeterminate results, and that may lead to a large, often discarded, number of blood bags as well. Therefore, we note that it is essential to adopt strategies that allow for the safe identification of a donor with positive serology for Chagas, so as to reduce or eliminate indeterminate serological results. Among these strategies, the development of specific serological tests would reduce the rate of indeterminate results ${ }^{6}$.

According to DIAS \& SCHOFIELD (1998) ${ }^{4}$, studies on the prevalence of Chagas disease in blood donors may be deemed sensitive, as they establish notions of the risk of transfusional Chagas disease and even suggest the level of transmission of the disease in a given region.

The data obtained in this study showed that the prevalence of Chagas disease in blood donors at the Hemominas center in Ituiutaba is consistent with the outcomes of other studies. Most ineligible serological results were found to be indeterminate, hence the need for further research to implement strategies allowing for a safe identification of the chagasic donor, thus reducing equivocal or indeterminate results.

A study analyzed secondary data from various blood banks in Brazil in order to assess blood banks indicators. The following data were analyzed: the rate of serological ineligibility for $T$. cruzi, the rate of discarded blood bags, and the rate of inconclusive serology. In blood banks in which ELISA serological test was used, there was 100\% sensitivity and $92-100 \%$ specificity ${ }^{20}$. Thus, this technique may facilitate the identification of ineligible donors (positive or indeterminate), ensuring greater safety throughout the serological screening process. It should be emphasized that ELISA has been used for screening tests in Ituiutaba's blood bank since 1992 .

The dynamics of Chagas disease transmission in Latin America has undergone significant changes in recent years. There has been a reduction in the number of infected people (from 16 million to 7.6 million) and in donor seroprevalence (from $8.4 \%$ to $1.3 \%$ ), as well as increased serological coverage $(86.8 \%$ ). In endemic countries for Chagas disease, including Brazil, there is a distinct profile in notifications of the disease. This is due to the control of vector-borne diseases and improvement of serological screening techniques. However, the situation is different in non-endemic countries ${ }^{16,18}$. 
LOPES, P.S.; RAMOS, E.L.P.; GÓMEZ-HERNÁNDEZ, C.; FERREIRA, G.L.S. \& REZENDE-OLIVEIRA, K. - Prevalence of Chagas disease among blood donor candidates in Triangulo Mineiro, Minas Gerais State, Brazil. Rev. Inst. Med. Trop. Sao Paulo, 57(6): 461-5, 2015.

Studies have shown a displacement of Chagas disease to Japan, Australia, USA and countries in Europe. This fact can be explained by the migration of people from endemic areas, for instance, Latin America. In most cases, the patients diagnosed in these areas are in the chronic indeterminate phase of the disease. Countries such as Spain, which receives many immigrants from Latin America, is considered to have the highest number of cases, with a present seroprevalence of $31 \% \%^{2,15}$. Hence, it is of paramount importance to perform serological screening of blood or organ donors from non-endemic areas considered at risk, as well as from endemic areas ${ }^{3}$.

In our study, the occurrence of ineligible donors was analyzed from 1991 to 2011 in the Hemocentro (regional hematology center) in Ituiutaba, Minas Gerais State, Brazil. The data showed a lower incidence of Chagas disease cases in donors under the age of 20 (5.4\%) and donors aged 20-29 years (16.9\%). These donors represent a reduction in chagasic individuals in the age group of people who are able to donate blood, and an increase in unfit donor exclusion, although cases reported by the Brazilian National Disease Notification System (SINAN), from 2007 to 2013, demonstrated a higher prevalence of Chagas disease between 20-30 year-old donors ( $30.9 \%$ of the 1,130 reported cases $)^{21}$.

Outbreaks of acute Chagas disease related to ingestion of contaminated food (sugar cane juice and açai, representing 70.7\% of the 1,130 reported cases) and also to transmission cases isolated by extradomiciliary vector $(7.5 \%)$ were reported from 2007 to 2013 , especially in Para, northern Brazil ${ }^{21}$. Oral contamination demonstrates a new transmission dynamics of the disease, representing a risk to the population. As for vector transmission, in regions with imminent risk, as is the case for Minas Gerais State, epidemiological surveillance actions aim to detect the presence of residential colony vectors and prevent their formation, which could explain the low percentage of people infected via this means of transmission ( $0.17 \%$ of the 1,130 reported cases $)^{21}$.

This study demonstrates an important change in the dynamics of transfusion transmission of Chagas disease in the town of Ituiutaba, in Minas Gerais State, Brazil. As noted in other Brazilian States, improvement of serological techniques (sensitivity and specificity) and vector control measures have contributed to the decrease in reported cases of the disease and the decrease in disposal of blood bags of donors considered ineligible for donation.

\section{RESUMO}

\section{Prevalência de casos de doença de Chagas em candidatos a doação de sangue na região do Pontal do Triângulo Mineiro, Brasil}

A doença de Chagas, apesar das campanhas de saúde pública e das ações de vigilância epidemiológica, ainda constitui-se um sério problema de saúde na América Latina. De acordo com dados divulgados pela Organização Mundial de Saúde, existem cerca de 7 a 8 milhões de pessoas infectadas com Trypanosoma cruzi em todo o mundo, principalmente na América Latina. Este estudo tem por objetivo analisar o perfil sorológico de doadores de sangue dos bancos de sangue do Hemominas de Ituiutaba, Minas Gerais. Os doadores também foram separados de acordo com o sexo e a idade. A amostra do estudo foi composta por 53.941 doadores de sangue durante o período de janeiro de 2001 a dezembro de 2011. Duzentos e setenta e sete doações (0,5\%) foram considerados sorologicamente inaptas para a doença de Chagas. Quanto à idade, a maior proporção de doadores impróprios foi de 40 a 49 anos (30\%). Os dados não revelaram diferença significativa entre os sexos $(p<0,05)$. Houve correlação positiva entre o aumento da idade e o percentual de pacientes soropositivos para doença de Chagas. É imprescindível a adoção de estratégias que permitam a identificação segura de um doador com sorologia positiva para doença de Chagas, tentando assim minimizar ou eliminar resultados sorológicos indeterminados.

\section{ACKNOWLEDGEMENTS}

Fábia Lima de Macedo Aidar and Daniela Roberta Curcino from the Hemominas (hematology center) in Ituiutaba, Minas Gerais, Brazil, for providing data for the implementation of the study, and also Josiane Nogueira Müller for her invaluable help with the results.

\section{REFERENCES}

1. Blejer JL, Saguier MC, Salamone HJ. Antibodies to Trypanosoma cruzi among blood donors in Buenos Aires, Argentina. Int J Infect Dis. 2001;5:89-93.

2. Cortez J, Providencia R, Ramos E, Valente C, Seixas J, Meruje M, et al. Emerging and under-recognized Chagas cardiomyopathy in non-endemic countries. World $\mathrm{J}$ Cardiol. 2012;4:234-9.

3. Dias JC. Southern Cone Initiative for the elimination of domestic populations of Triatoma infestans and the interruption of transfusional Chagas disease. Historical aspects, present situation, and perspectives. Mem Inst Oswaldo Cruz. 2007;102 (Suppl 1):11-8

4. Dias JC, Schofield CJ. Controle da transmissão transfusional da doença de Chagas na Iniciativa do Cone Sul. Rev Soc Bras Med Trop. 1998;31:373-83.

5. Dias JC, Silveira AC, Schofield CJ. The impact of Chagas disease control in Latin America: a review. Mem Inst Oswaldo Cruz. 2002;97:603-12.

6. Ferreira I de L, Silva TP. Eliminação da transmissão da doença de Chagas pelo Triatoma infestans no Brasil: um fato histórico. Rev Soc Bras Med Trop. 2006;39:5079.

7. Fitarelli DB, Horn JF. Descarte de bolsas de sangue devido à reatividade para doença de Chagas em um laboratório de triagem sorológica de doadores em Porto Alegre-RS. Rev Bras Hematol Hemoter. 2009;31:310-4.

8. Jannin J, Salvatelli R. Estimación cuantitativa de la enfermedad de Chagas en las Americas. Montevideo: Organizacíon Panamericana de la Salud; 2006. (OPS/ HDM/ CD/ 425-06).

9. Lunardelli A, Borges FP, Mello KF, Zeferino ASA. Soroprevalência da doença de Chagas em candidatos a doadores de sangue. Rev Bras Anal Clin. 2007;39:139-41.

10. Medei EH, Nascimento JH, Pedrosa RC, Carvalho AC. Role of autoantibodies in the physiopathology of Chagas' disease. Arq Bras Cardiol. 2008;91:257-62.

11. Melo AS, Lorena VMB, Moraes AB, Pinto MBA, Leão SC, Soares AKA, et al. Prevalência de infecção chagásica em doadores de sangue no estado de Pernambuco, Brasil. Rev Bras Hematol Hemoter. 2009;31:69-73.

12. Moncayo A. Progress towards interruption of transmission of Chagas disease. Mem Inst Oswaldo Cruz. 1999;94 (Suppl 1):401-4.

13. Moraes-Souza H, Martins PRJ, Pereira GA, Ferreira-Silva MM, Abud MB. Perfil sorológico para doença de Chagas dos doadores de sangue do Hemocentro Regional de Uberaba. Rev Bras Hematol Hemoter. 2006;28:110-4. 
LOPES, P.S.; RAMOS, E.L.P.; GÓMEZ-HERNÁNDEZ, C.; FERREIRA, G.L.S. \& REZENDE-OLIVEIRA, K. - Prevalence of Chagas disease among blood donor candidates in Triangulo Mineiro, Minas Gerais State, Brazil. Rev. Inst. Med. Trop. Sao Paulo, 57(6): 461-5, 2015.

14. Oliveira-Marques DS, Bonametti AM, Matsuo T, Gregori Junior F. The epidemiologic profile and prevalence of cardiopathy in Trypanosoma cruzi infected blood donor candidates, Londrina, Paraná, Brazil. Rev Inst Med Trop Sao Paulo. 2005;47:321-6.

15. Pérez-Ayala A, Pérez-Molina JA, Norman F, Navarro M, Monge-Maillo B, DíazMenendez M, et al. Chagas disease in Latin American migrants: a Spanish challenge. Clin Microbiol Infect. 2011;17:1108-13.

16. Schmunis GA. Epidemiology of Chagas disease in non-endemic countries: the role of international migration. Mem Inst Oswaldo Cruz. 2007;102 (Suppl 1):75-85.

17. Schmunis GA. Trypanosoma cruzi, the etiologic agent of Chagas' disease: status in the blood supply in endemic and nonendemic countries. Transfusion. 1991;31:547-57.

18. Schmunis GA, Cruz JR. Safety of the blood supply in Latin America. Clin Microbiol Rev. 2005;18:12-29.

19. Silva MMF. Sensibilidade e especificidade dos testes sorológicos para doença de Chagas usados na triagem sorológica de doadores de sangue [dissertação]. Uberaba: Universidade Federal do Triângulo Mineiro; 2006.
20. Silva VLC, Luna EJA. Prevalência de infecção pelo T. cruzi em doadores de sangue nos hemocentros coordenadores do Brasil em 2007. Epidemiol Serv Saúde. 2013;22:10310 .

21. SINAN. Sistema de Informação de Agravos de Notificação. Brasília: Ministério da Saúde; 2004. Available from: http://dtr2004.saude.gov.br/sinanweb/tabnet/ tabnet?sinannet/chagas/bases/chagasbrnet.def

22. Sobreira ACM, Gomes FVBAF, Silva MAM, Oliveira MF. Prevalência de infecção chagásica em doadores de sangue do Hemocentro Regional de Iguatu, CE. Rev Soc Bras Med Trop. 2001;34:193-6.

23. Umezawa ES, Silveira JF. Serological diagnosis of Chagas disease with purified and defined Trypanosoma cruzi antigens. Mem Inst Oswaldo Cruz. 1999;94 (Suppl 1):285-

24. Villela MM, Pimenta DN, Lamounier PA, Dias JCP. Avaliação de conhecimentos e práticas que adultos e crianças têm acerca da doença de Chagas e seus vetores em região endêmica de Minas Gerais, Brasil. Cad Saude Publica. 2009;25:1701-10.

Received: 10 June 2014

Accepted: 06 April 2015 


\section{Revista do Instituto de Medicina Tropical de São Paulo on line.}

Publications from 1984 to the present data are now available on:

http://www.scielo.br/rimtsp

PAST ISSUES FROM 1959 ON (PDF)

www.imt.usp.br/portal/

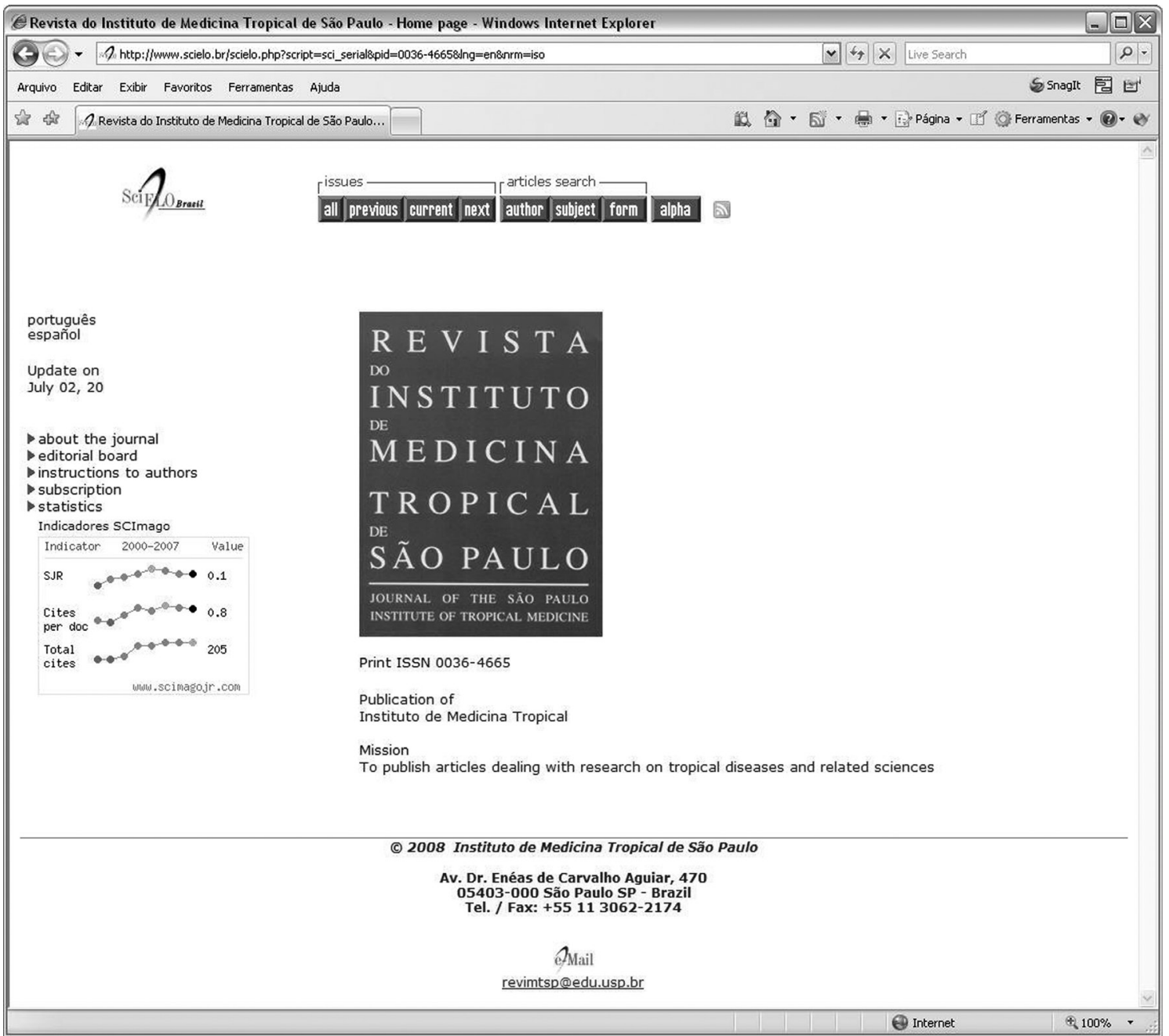

SciELO - The Scientific Electronic Library OnLine - SciELO is an electronic virtual covering a selected collection of Brazilian scientific journals.

The library is an integral part of a project being developed by FAPESP - Fundação de Amparo à Pesquisa do Estado de São Paulo, in partnership with BIREME - the Latin American and Caribbean Center on Health Sciences Information.

SciELO interface provides access to its serials collection via an alphabetic list of titles or a subject index or a search by word of serial titles, publisher names, city of publication and subject.

The interface also provides access to the full text of articles via author index or subject index or a search form on article elements such as author names, words from title, subject and words from full text.

FAPESP/BIREME Project on Scientific Electronic Publications Latin American and Caribbean Center on Health Sciences Information

Rua Botucatu 862 - 04023-901 São Paulo, SP - Brazil

Tel. (011) 5576-9863

scielo@bireme.br 